\title{
ANALISIS BEBAN KERJA UNTUK PERENCANAAN KEBUTUHAN SUMBER DAYA MANUSIA (SDM) BIDANG BINA MARGA DINAS PEKERJAAN UMUM DAN PENATAAN RUANG (PUPR) KABUPATEN LOMBOK BARAT
}

\author{
Rahmat Hidayat ${ }^{1}$ \\ Agusdin $^{2}$ \\ Dwi Putra Buana Sakti ${ }^{3}$ \\ 1Program Studi Magister Manajemen Fakultas Ekonomi dan Bisnis Unram \\ Email : rahmat13666@gmail.com \\ ${ }^{2}$ Fakultas Ekonomi dan Bisnis Unram \\ Email : agusdin@unram.ac.id \\ ${ }^{3}$ Fakultas Ekonomi dan Bisnis Unram \\ Email : dwiputrabs39@unram.ac.id
}

\begin{tabular}{|c|c|}
\hline ARTICLE INFO & ABSTRACT \\
\hline $\begin{array}{l}\text { Keywords : } \\
\text { Workload, Human Resource Planning, } \\
\text { Human Resource Needs, Workload } \\
\text { Indicators of Staffing Need, Business } \\
\text { Management } \\
\text { How to cite: } \\
\text { Hidayat, R., Agusdin., Sakti, Dwi Putra } \\
\text { Buana (2018). Analisis Beban Kerja Untuk } \\
\text { Perencanaan Kebutuhan Sumber Daya } \\
\text { Manusia (SDM) Bidang Bina Marga Dinas } \\
\text { Pekerjaan Umum Dan Penataan Ruang } \\
\text { (PUPR) Kabupaten Lombok Barat. } \\
\text { JMM UNRAM, 7(3), } 45 \text { - } 60 \\
\text { DOI : } \\
\text { 10.29303/jmm.v7i3.314 }\end{array}$ & $\begin{array}{l}\text { This study aims to analyze the workload of each work unit } \\
\text { and HR category, analyze the needs of the number and } \\
\text { competency of HR and analyze the investment costs of } \\
\text { procurement and compensation for HR needs in the } \\
\text { Highways Division of the PUPR Office of West Lombok } \\
\text { Regency. The population in this study were all employees } \\
\text { who worked in the Highways Division of the PUPR Office } \\
\text { of West Lombok Regency totaling } 39 \text { people. Census method } \\
\text { as a data collection method used. The data analysis technique } \\
\text { used in this study is WISN (Workload Indicators of Staffing } \\
\text { Need). The results showed that the workload in each unit of } \\
\text { Bina Marga was still not optimal, the Marga field still } \\
\text { lacked } 10 \text { employees and still needed competency } \\
\text { improvement, the results of the analysis also showed the type } \\
\text { of procurement that must be carried out by the Highways } \\
\text { Division with compensation costs in accordance with } \\
\text { applicable guidelines } \\
\text { Penelitian ini bertujuan untuk menganalisis beban kerja } \\
\text { masing-masing unit kerja dan kategori SDM, menganalisis } \\
\text { kebutuhan jumlah dan kompetensi SDM dan menganalisis } \\
\text { biaya investasi pengadaan dan kompensasi kebutuhan SDM } \\
\text { di Bidang Bina Marga Dinas PUPR Kabupaten Lombok } \\
\text { Barat. Populasi pada penelitian ini adalah seluruh karyawan } \\
\text { yang bekerja pada Bidang Bina Marga Dinas PUPR }\end{array}$ \\
\hline
\end{tabular}




\begin{tabular}{|l|l|}
\hline & $\begin{array}{l}\text { Kabupaten Lombok Barat yang berjumlah 39 orang. Metode } \\
\text { sensus sebagai metode pengumpulan data yang di gunakan. } \\
\text { Teknik analisis data yang digunakan dalam penelitian ini } \\
\text { adalah WISN (Workload Indicators of Staffing Need). Hasil } \\
\text { penelitian menunjukan bahwa beban kerja pada setiap unit } \\
\text { Bidang Bina Marga masih belum optimal, Bidang bina } \\
\text { Marga masih kekurangan 10 orang karyawan dan masih } \\
\text { membutuhkan peningkatan kompetensi, hasil analisis juga } \\
\text { menunjukan jenis pengadaan yang harus dilakukan Bidang } \\
\text { Bina Marga dengan biaya kompensasi sesuai dengan } \\
\text { pedoman yang berlaku. }\end{array}$ \\
\hline
\end{tabular}

\section{PENDAHULUAN}

Perencanaan sumber daya manusia adalah proses mengenai pembuatan kebijakan baru, sistem dan program yang menjamin pengolahan SDM di bawah kondisi yang tidak pasti (Rivai, 2004:36). Sedangkan menurut Notoatmojo, (2003) Perencanaan sumber daya manusia adalah serangkaian kegiatan yang dilakukan untuk mengantisipasi permintaan (demand) bisnis dan lingkungan pada organisasi di waktu yang akan datang serta untuk memenuhi kebutuhan tenaga kerja yang ditimbulkan kondisi tersebut.

Bidang Bina Marga Dinas Pekerjaan Umum dan Penataan Ruang (PUPR) Kabupaten Lombok Barat memiliki tugas merumuskan dan melaksanakan kebijakan teknis perencanaan, pembangunan, peningkatan dan pemeliharaan prasarana ke bina margaan meliputi jalan sepanjang $571 \mathrm{Km}$ yang terdiri dari 237 jenis ruas jalan. Dalam melaksanakan tugasnya, Bidang Bina Marga didukung oleh 41 orang karyawan (32 karyawan teknis dan 9 karyawan non teknis) dan terdiri dari 3 (tiga) seksi yaitu Seksi Perencanaan Teknis dan Pengendalian, Seksi Pembangunan dan Peningkatan, dan Seksi Pemeliharaan. Semua pembiayaan pekerjaan-pekerjaan tersebut bersumber dari Anggaran Pendapatan dan Belanja Daerah (APBD), Dana Alokasi Khusus (DAK), dan Dana Alokasi Umum (DAU).

Berdasarkan penilaian awal peneliti, ada sejumlah ketidakseimbangan antara jumlah dan kompetensi karyawan dengan beban kerja masing-masing Unit Kerja. Beberapa orang karyawan bekerja melebihi jam kerja karena harus membantu pekerjaan unit lainnya yang seharusnya bukan menjadi tanggung jawabnya seperti Kepala Seksi yang merangkap jabatan sebagai PPK. Jabatan penyusun rencana program pada seksi perencanaan kini kosong karena karyawan pada bagian tersebut sedang melanjutkan pendidikan sejak tahun 2016 lalu, sehingga beban kerja pada bagian tersebut harus dilimpahkan kepada karyawan lainya. Terdapat beberapa karyawan yang melaksanakan aktivitas pekerjaan yang tidak sesuai dengan tugas pokok dan fungsinya, pada Seksi Perencanaan, terdapat pengadministrasi kegiatan yang difungsikan sebagai penata keuangan dan bendahara seksi dan tidak pernah melaksanakan pekerjaannya sebagai pengadministrasi kegiatan. Kemudian pada seksi pembangunan dan peningkatan terdapat beberapa orang pengawas jalan dan jembatan yang difungsikan sebagai pengawas utama. Pada seluruh seksi, jabatan pengadministrasi kegiatan merangkap sebagai pembantu bendahara seksi yang membuat beban kerja mereka menjadi tinggi. 
Beban puncak pekerjaan masing-masing seksi sepanjang tahun 2017 berbeda-beda. Seksi Perencanaan dan Pengendalian mengalami beban puncak pekerjaan pada bulanbulan di awal tahun, sedangkan pekerjaan-pekerjaan Seksi Pembangunan dan Peningkatan dan Seksi Pemeliharaan mengalami beban puncak pekerjaan pada pertengahan tahun sampai dengan akhir tahun. Beban kerja adalah frekuensi kegiatan rata-rata dari masingmasing jenis pekerjaan dalam jangka waktu tertentu (Moekijat, 1999). Salah satu metode perhitungan analisis beban kerja adalah metode estimasi beban kerja yaitu suatu metode penyusunan kebutuhan berdasarkan Workload Indicator of Staffing Needed (WISN). Metode WISN ini adalah metode untuk menetapkan jumlah tenaga berdasarkan jenis kegiatan dan volume pelayanan pada suatu unit atau institusi (WHO, 2010).

Setelah mendapatkan hasil dan rekomendasi dari analisis beban kerja dengan WISN, selanjutnya peneliti dapat menghitung biaya investasi untuk pengadaan dan kompensasi kebutuhan SDM. Untuk menghitung biaya tersebut adalah dengan menggunakan pedoman pada biaya rekrutmen dan kompensasi menggunakan standar yang berlaku.

Berdasarkan latar belakang diatas maka diperlukan tahapan untuk mengetahui beban kerja bagi masing-masing karyawan dan unit kerja melalui analisis beban kerja. Analisis beban kerja bertujuan untuk meningkatkan optimalisasi kinerja instansi pemerintah. Hasil analisis beban kerja dapat dijadikan sebagai bahan untuk menata organisasi sesuai kebutuhan penyelesaian tugas pokok dan fungsi yang menjadi tanggung jawabnya. Analisis beban kerja merupakan studi/kajian guna mendapatkan gambaran pelaksanaan kerja atau banyaknya uraian tugas yang harus dilaksanakan oleh suatu organisasi atau unit organisasi.

Adapun kerangka konseptual dalam penelitian ini adalah sebagai berikut:

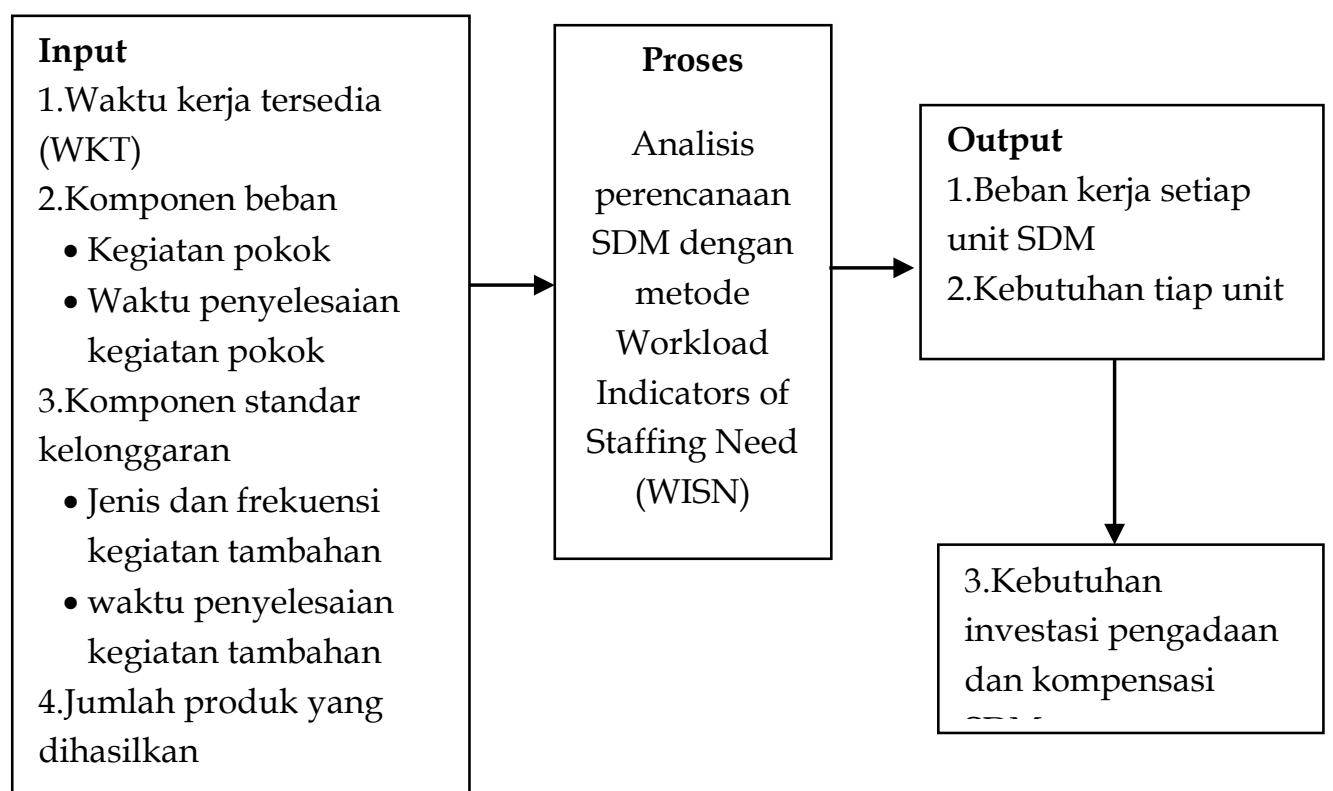

Gambar 1. Kerangka Konseptual Penelitian 


\section{KAJIAN TEORI}

\subsection{Analisis beban kerja}

Salah satu cara melakukan perencanaan sumber daya manusia adalah dengan analisis beban kerja (Kepmenkes No.81, 2004). Perencanaan tenaga kerja baik mikro ataupun makro dihitung berdasarkan beban kerja yang kemudian dituangkan dalam rencana tenaga kerja yang disusun dalam jangka waktu lima tahun (Peraturan Pemerintah No. 15, 2007). Analisis beban kerja adalah proses untuk menetapkan jumlah jam kerja orang yang digunakan atau dibutuhkan untuk merampungkan suatu pekerjaan dalam waktu tertentu atau dengan kata lain analisis beban kerja bertujuan untuk menentukan berapa jumlah personalia dan berapa jumlah tanggung jawab atau beban kerja yang tepat dilimpahkan kepada seorang petugas. Menurut Wideman (2002) dalam Hardjawinata (2006) mendefinisikan beban kerja adalah jumlah unit kerja yang ditugaskan pada satu sumber daya dalam periode waktu tertentu. Kebutuhan ini akan berkembang menyesuaikan dengan tuntutan dan perkembangan organisasi sehingga perlu dilakukan penilaian tiap tahunnya.

Hasil dari perhitungan analisis beban kerja sangat bermanfaat sebagai alat ukur terhadap kebutuhan sumber daya manusia dalam sebuah organisasi sebagai dasar dalam norma waktu penyelesaian kerja, tingkat efisiensi kerja, prestasi kerja, penyusunan formasi pegawai, dan penyempurnaan sistem prosedur kerja (Kepmenkes Bidang Kesra No.54, 2013). Berbagai metode yang telah dikembangkan dapat dijadikan patokan dalam melakukan analisis beban kerja. Metode yang paling akurat untuk peramalan jangka pendek saat ini adalah dengan menghitung beban kerja (workload) yang merupakan analisis pekerjaan terhadap beban kerja yang perlu disesuaikan (Simamora, 2006:141). Adapun manfaat dari melakukan analisis beban kerja adalah:

1. Penyusunan rencana kebutuhan pegawai secara riil sesuai dengan beban kerja organisasi

2. Penyusunan standar beban kerja jabatan/kelembagaan

3. Penilaian prestasi kerja jabatan dan prestasi kerja unit

4. Sarana peningkatan kinerja kelembagaan

5. Program mutasi pegawai dari unit yang berlebihan ke unit yang kekurangan

6. Reward and Punishment terhadap unit atau pejabat

7. Bahan penetapan kebijakan bagi pimpinan dalam rangka peningkatan pendayagunaan sumber daya manusia

\subsection{Workload indicators of staffing need (WISN)}

Workload Indicators of Staffing Need (WISN) merupakan sebuah standar pengukuran kebutuhan tenaga kerja berdasarkan indikator beban kerja yang pertama kali di ujicobakan sekitar tahun 1998. Metode WISN adalah alat manajemen sumber daya yang menghitung kebutuhan staf berdasarkan beban kerja untuk kategori staf tertentu dan jenis fasilitas. Alat ini dapat diterapkan secara nasional maupun regional. Metode WISN memiliki kelebihan yaitu mudah digunakan baik secara teknis, komprehensif, realistis serta memberikan kemudahan dalam menentukan variasi kebutuhan SDM dalam berbagai tipe. Namun metode WISN memiliki kelemahan, dimana sangat diperlukan adanya kelengkapan data yang nantinya akan dianalisa secara statistik dan akan mempengaruhi akurasi hasil WISN (WHO, 2010). Ozcan dan Homby (1999) dalam Eska dan Widodo (2015) juga menyatakan data yang digunakan dalam perhitungan WISN adalah rincian aktivitas yang ada pada 
tahun sebelumnya. Hal tersebut menjadi kelemahan metode WISN bahwa hasil perhitungan mungkin akan selalu berbeda setiap tahunnya karena standar aktivitas dari tahun ke tahun kemungkinan akan selalu berbeda. Langkah kerja dalam metode WISN sesuai dengan pedoman WHO tahun 2010.

1) Menentukan prioritas jenis tenaga kerja dan tipe fasilitas.

2) Memperkirakan waktu kerja yang tersedia.

3) Mendefinisikan komponen-komponen beban kerja.

4) Menentukan standar aktivitas.

5) Menentukan standar beban kerja.

6) Menghitung faktor kelonggaran.

7) Menetapkan kebutuhan tenaga berdasarakan WISN.

8) Analisis dan interpretasi hasil WISN.

Analisis hasil WISN terdiri dari perbedaan antara tenaga yang ada dengan tenaga yang diperlukan dan penghitungan rasio WISN. Rasio WISN adalah pengukuran terhadap tekanan beban kerja sehari-hari dari tenaga kesehatan. Menguji kedua hal antara gap dan juga rasio WISN adalah sangat penting dalam menentukan bagaimana cara dalam pengembangan tenaga kesehatan secara wajar (WHO, 2010). Penerapan metode WISN memberikan manfaat cukup besar dalam pengelolaan SDM dalam suatu organisasi.

1) Perencanaan ketenagaan mendatang

Pemanfaatan pertama yang dilakukan sesuai dengan hasil WISN adalah sebagai dasar dalam perencanaan kebutuhan mendatang akan tenaga kerja pada organisasi bersangkutan. Perencanaan ini harus mampu mengantisipasi akan munculnya beban kerja lain dengan meningkatkan standar profesi sesuai dengan standar terbaru yang relevan, memperhitungkan perubahan kondisi ketenagaan melihat dari waktu kerja tersedia, dan juga melakukan penyesuaian standar sesuai rata-rata waktu yang telah dihitung (WHO, 2010).

2) Pengalokasian tenaga kerja

Hasil dari WISN akan dapat memberikan gambaran akan dampak dari kurangnya tenaga kerja yang tersedia. Melalui upaya pengalokasian tenaga kerja diharapkan dapat membantu meringankan beban kerja tenaga kerja bersangkutan. Apabila menambah jumlah tenaga tidak memungkinkan bisa diatasi dengan mengatur waktu kerja dengan cara bergantian (WHO, 2010).

3) Peningkatan kualitas tenaga kerja

Rasio WISN yang rendah akan berakibat terhadap rendahnya kualitas keluaran dari pelayanan yang diberikan. Upaya-upaya untuk meningkatkan kualitas tenaga kerja menjadi prioritas sesuai hasil WISN apabila dengan menambah jumlah tenaga sangat tidak memungkinkan (WHO, 2010).

4) Upaya pendistribusian tenaga kerja yang ada saat ini serta mengurangi tekanan beban kerja

Membandingkan hasil dari WISN pada tempat yang serupa akan dapat membantu kita dalam pendistribusian dengan tepat. Tempat mana yang terlihat terjadi kekurangan tenaga kerja, berapa besar tekanan beban kerjanya bisa sebagai dasar untuk melakukan pemerataan distribusi tenaga kerja (WHO, 2010). 


\section{METODE PENELITIAN}

\subsection{Jenis Penelitian}

Penelitian ini merupakan penelitian deskriptif dengan pendekatan kuantitatif. Penelitian deskriptif merupakan penelitian dengan tujuan untuk membuat deskripsi, gambaran, atau lukisan secara sistematis, faktual dan akurat mengenai fakta-fakta, sifat serta hubungan antar fenomena yang diselidiki (Nazir, 2003). Pada penelitian ini pendekatan kuantitatif digunakan untuk menghitung beban kerja dan kebutuhan SDM dengan metode WISN. Pendekatan kuantitatif juga digunakan untuk mengetahui biaya investasi untuk pengadaan dan kompensasi kebutuhan SDM Bidang Bina Marga Dinas PUPR di Kab. Lombok Barat.

\subsection{Lokasi Penelitian}

Penelitian ini dilakukan di Bidang Bina Marga Dinas Pekerjaan Umum dan Penataan Ruang (PUPR) yang berlokasi di Kabupaten Lombok Barat Provinsi Nusa Tenggara Barat.

\subsection{Metode pengumpulan data}

Metode pengumpulan data yang digunakan dalam penelitian ini adalah metode sensus. Dalam hal ini, data berasal dari semua subjek dalam populasi, tidak hanya dari sampel, (Sangdji, 2010:31).

\subsection{Penentuan Responden}

Populasi adalah kelompok individu yang memiliki karakteristik yang sama atau relatif sebagai suatu kelompok besar dan kesatuan sampel yang hendak diteliti, Creswell (Herdiansyah, 2010:103). Populasi dari penelitian ini adalah karyawan Dinas PUPR Bidang Bina Marga yang ada di wilayah Kabupaten Lombok Barat. Dalam penelitian ini semua populasi diambil sebagai responden yaitu sejumlah 39 orang.

\subsection{Teknik Dan Alat Pengumpulan Data}

Teknik pengumpulan data adalah bagian dari instrumen pengumpulan data yang menentukan keberhasilan tujuan suatu penelitian (Bungin, 2009). Teknik pengumpulan data yang dipakai dalam penelitian ini adalah:

1. Teknik dokumentasi

Metode dokumentasi adalah proses mencari mengenai hal-hal atau variabel yang berupa catatan, transkip, buku, surat kabar, majalah, prasasti, notulen rapat, agenda, dan sebagainya. Dokumen dapat berupa tulisan, gambar, atau karya-karya monumental dari seseorang, Arikunto (2006:151),

2. Teknik angket

Teknik angket adalah teknik pengumpulan data dengan menggunakan sejumlah pertanyaan tertulis yang harus diisi oleh responden untuk mendapatkan informasi. Alat yang dipakai berupa template yang berisi daftar jenis dan kategori SDM, kegiatan (pokok, penunjang/tambahan) dari masing-masing kategori SDM, uraian tugas, frekuensi kegiatan, dan waktu yang dibutuhkan untuk menyelesaikan setiap kegiatan.

3. Wawancara (Semi-structured interview)

Wawancara adalah proses memperoleh keterangan untuk tujuan penelitian dengan cara tanya jawab sambil bertatap muka antara pewawancara dengan responden dengan menggunakan alat yang dinamakan interview guide.

\subsection{Jenis Dan Sumber Data}

\subsubsection{Jenis data}

Jenis data yang digunakan dalam penelitian ini adalah data kuantitatif dan data kualitatif. Data kuantitatif adalah data yang ditampilkan dalam bentuk angka 
sedangkan data kualitatif adalah data yang disajikan dalam bentuk kata-kata yang memiliki makna.

\subsubsection{Sumber data}

Sumber data dalam penelitian ini dikumpulkan dari data primer yang berasal dari responden penelitian berupa angket (template kegiatan) setiap kategori SDM dan hasil wawancara tentang perencanaan kebutuhan SDM dari responden penelitian. Data juga diperoleh dari sumber data sekunder yaitu data pendukung yang diperoleh dari literatur-literatur atau kajian pustaka penelitian yang ada kaitannya dengan penelitian.

\section{HASIL DAN PEMBAHASAN}

\subsection{Hasil pengolahan data kuantitatif}

a) Kategori tenaga yang ada di Bidang Bina Marga

Berdasarkan data primer yang diperoleh pada Bidang Bina Marga Dinas PUPR Kabupaten Lombok Barat yang dijadikan sampel, maka dapat disajikan kategori tenaga yang ada pada organisasi sebagai berikut.

Tabel 4.6. Kategori SDM Bidang Bina Marga Dinas PUPR

\begin{tabular}{|l|l|c|}
\hline No. & \multicolumn{1}{|c|}{ Kategori SDM } & Jumlah \\
\hline 1. & Kepala Bidang & 1 \\
\hline 2. & Kepala Seksi & 3 \\
\hline 3. & Penyusun rencana program & 2 \\
\hline 4. & Pengumpul dan pengolah data & 3 \\
\hline 5. & pengadministrasi umum dan kegiatan & 8 \\
\hline 6. & Pengawas utama & 1 \\
\hline 7. & Pengawas jalan dan jembatan & 9 \\
\hline 8. & Juru jalan dan jembatan & 9 \\
\hline 9. & Pelaksana teknis jalan dan jembatan & 1 \\
\hline 10. & Pembantu umum & 2 \\
\hline Jumlah kategori SDM & 39 \\
\hline
\end{tabular}

Sumber: Data primer diolah, 2018

Berdasarkan tabel tersebut diatas dapat dilihat Bidang Bina Marga Dinas PUPR memiliki 10 kategori tenaga.

b) Unit kerja yang ada di Bidang Bina Marga

Berikut disajikan dalam tabel 4.7. unit-unit kerja yang terdapat pada Bidang Bina Marga Dinas PUPR beserta kategori tenaga yang ada didalamnya.

Tabel 4.7. Unit Kerja dan Kategori SDM Bidang Bina Marga

\begin{tabular}{|c|l|c|}
\hline No & \multicolumn{1}{|c|}{ Unit Kerja } & Jumlah \\
\hline I & Bidang Bina Marga & 1 \\
\hline A & Seksi Perencanaan dan Pengendalian & 11 \\
\hline B & $\begin{array}{l}\text { Seksi Pembangunan dan } \\
\text { Peningkatan }\end{array}$ & 10 \\
\hline C & Seksi Pemeliharaan & 17 \\
\hline \multicolumn{2}{|c|}{ Total } & 39 \\
\hline
\end{tabular}

Sumber: Data primer diolah, 2017 
Berdasarkan tabel 4.7. diatas jumlah unit kerja yang ada di Bidang Bina Marga sebanyak 3 unit. Unit- unit kerja yang ada di Bidang Bina Marga terdiri atas: Seksi perencanaan dan pengendalian, unit seksi pembangunan dan peningkatan, unit seksi pemeliharaan.

c) Waktu kerja tersedia

Menurut ketetapan Menteri Negara Pendayagunaan Aparatur Negara (MENPAN) tentang perhitungan jam efektif waktu kerja Pegawai Negeri Sipil dibuatkan standar sebagaimana tampak pada tabel berikut:

Tabel 4.8. waktu kerja tersedia karyawan Bidang Bina Marga

\begin{tabular}{|c|l|c|c|}
\hline Kode & \multicolumn{1}{|c|}{ Faktor } & Waktu & Keterangan \\
\hline HK & Hari Kerja $(52$ minggu $\times 5$ hari) & 260 & Hari/tahun \\
\hline CT & Cuti Tahunan & 10 & Hari/tahun \\
\hline HLN & Hari Libur Nasional & 19 & Hari/tahun \\
\hline WK & Waktu Kerja $(100 \%)$ & 7.5 & Jam/hari \\
\hline WKE & Waktu Kerja Efektif $(80 \%)$ & 6.00 & Jam/hari \\
\hline \multicolumn{2}{|c|}{ Hari Kerja Tersedia } & $\mathbf{2 3 1}$ & Hari/tahun \\
\hline \multirow{2}{*}{ Waktu Kerja Tersedia $(231 \times 6.00)$} & $\mathbf{1 3 8 6}$ & Jam/tahun \\
\cline { 3 - 4 } & & $\mathbf{8 3 , 1 6 0}$ & Menit/tahun \\
\hline
\end{tabular}

d) Menetapkan komponen beban kerja dan standar kegiatan

Komponen beban kerja terdiri atas kegiatan utama masing-masing kategori tenaga, kegiatan tambahan atau penunjang masing-masing kategori tenaga dan kegiatan tambahan lainnya yang hanya dikerjakan oleh beberapa orang dalam kategori tenaga tersebut. Setelah dihitung dengan rumus yang telah disediakan akan didapatkan standar beban kerja, standar kelonggaran kategori dan standar kelonggaran individu.

e) Beban kerja dan kebutuhan SDM setiap unit kerja Bidang Bina Marga

Berdasarkan data primer yang telah diolah maka dapat disajikan kebutuhan tenaga dan beban kerja setiap unit kerja dan setiap kategori tenaga yang ada di Bidang Bina Marga. Suluruh unit kerja yang ada pada Bidang Bina Marga memiliki tekanan beban kerja yang tinggi.

f) Kebutuhan tenaga setiap kategori SDM Bidang Bina Marga dan rasio WISN

Akumulasi kebutuhan setiap kategori SDM yang ada di Bidang Bina Marga dapat dilihat pada lampiran 8 dan 9. Berikut gambaran kebutuhan setiap kategori SDM dan rasio WISN setiap kategori SDM Bidang Bina Marga.

Tabel 4.10 Kebutuhan dan Rasio WISN Setiap Kategori SDM Bidang Bina Marga

\begin{tabular}{|c|c|c|c|c|c|c|}
\hline No. & Unit kerja & $\begin{array}{c}\text { Kategori SDM dalam } \\
\text { unit kerja }\end{array}$ & $\begin{array}{l}\text { Kebutu } \\
\text { han } \\
\text { SDM }\end{array}$ & $\begin{array}{c}\text { Terse } \\
\text { dia }\end{array}$ & Gap & $\begin{array}{l}\text { Rasio } \\
\text { WISN }\end{array}$ \\
\hline \multirow[t]{4}{*}{1.} & \multirow{4}{*}{$\begin{array}{l}\text { Seksi } \\
\text { Perencanaan } \\
\text { dan } \\
\text { Pengendalian }\end{array}$} & $\begin{array}{l}\text { Kepala Seksi } \\
\text { Perencanaan dan } \\
\text { Pengendalian }\end{array}$ & 2,54 & 1 & -1 & 0,5 \\
\hline & & $\begin{array}{l}\text { Penyusun Rencana } \\
\text { Program }\end{array}$ & 3,18 & 2 & -2 & 0,5 \\
\hline & & $\begin{array}{l}\text { Pengumpul dan } \\
\text { Pengolah Data }\end{array}$ & 2,28 & 2 & 0 & 1 \\
\hline & & $\begin{array}{l}\text { Juru Jalan dan } \\
\text { Jembatan }\end{array}$ & 1,18 & 1 & 0 & 1 \\
\hline
\end{tabular}




\begin{tabular}{|c|c|c|c|c|c|c|}
\hline & & $\begin{array}{l}\text { Pengadministrasi } \\
\text { Umum dan Kegiatan }\end{array}$ & 4,05 & 3 & -1 & 0,75 \\
\hline & & Pembantu Umum & 2,94 & 2 & -1 & 0,7 \\
\hline \multirow[t]{5}{*}{2.} & \multirow{5}{*}{$\begin{array}{l}\text { Seksi } \\
\text { Pembangunan } \\
\text { dan } \\
\text { Peningkatan }\end{array}$} & $\begin{array}{l}\text { Kepala Seksi/PPK } \\
\text { Pembangunan }\end{array}$ & 1,72 & 1 & -1 & 0,5 \\
\hline & & Pengawas Utama & 1,25 & 1 & 0 & 1 \\
\hline & & $\begin{array}{l}\text { Pengawas Jalan dan } \\
\text { Jembatan }\end{array}$ & 6,00 & 5 & -1 & 0,9 \\
\hline & & $\begin{array}{l}\text { Pengumpul dan } \\
\text { Pengolah Data }\end{array}$ & 1,01 & 1 & 0 & 1 \\
\hline & & $\begin{array}{l}\text { Pengadministrasi } \\
\text { Umum dan Kegiatan }\end{array}$ & 2,66 & 2 & -1 & 0,7 \\
\hline \multirow[t]{5}{*}{3.} & \multirow[t]{5}{*}{$\begin{array}{l}\text { Seksi } \\
\text { Pemeliharaan }\end{array}$} & $\begin{array}{l}\text { Kepala Seksi/PPK } \\
\text { Pemeliharaan }\end{array}$ & 2,08 & 1 & -1 & 0,5 \\
\hline & & $\begin{array}{l}\text { Pengawas Jalan dan } \\
\text { Jembatan }\end{array}$ & 4,51 & 4 & 0 & 1 \\
\hline & & $\begin{array}{l}\text { Juru Jalan dan } \\
\text { Jembatan }\end{array}$ & 7,76 & 8 & 0 & 1 \\
\hline & & $\begin{array}{l}\text { Pelaksana Teknis } \\
\text { Jalan dan Jembatan }\end{array}$ & 1,04 & 1 & 0 & 1 \\
\hline & & $\begin{array}{l}\text { Pengadminitrasi } \\
\text { Umum dan Kegiatan }\end{array}$ & 3,44 & 3 & -1 & 0,75 \\
\hline
\end{tabular}

Sumber: Data primer diolah, 2018

\subsection{Pembahasan hasil}

4.2.1. Beban kerja masing-masing unit kerja dan kategori SDM Bidang Bina Marga Dinas PUPR di Kabupaten Lombok Barat

A. Beban kerja setiap unit kerja Bidang Bina Marga

Setiap kategori tenaga dalam unit kerja Bidang Bina Marga memiliki tugas pokok dan tugas penunjang atau tambahan. Uraian tugas pokok yang dilaksanakan menjadi komponen dalam pengukuran beban kerja, sedangkan uraian tugas tambahannya menjadi faktor kelonggaran kategori. Setiap kegiatan/uraian tugas pokok kategori tenaga dalam unit kerja Bidang Bina Marga dihitung standar beban kerjanya dengan membagi waktu kerja tersedia (WKT) yang dimiliki kategori tenaga tersebut dengan waktu yang dibutuhkan untuk menyelesaikan kegiatan atau tugas pokoknya.

1. Unit seksi perencanaan dan pengendalian

Berdasarkan hasil perhitungan beban kerja di Bidang Bina Marga dengan metode WISN ditemukan rasio WISN 0,7 untuk unit seksi perencanaan dan pengendalian. Dalam pedoman manual WISN, sebuah rasio WISN bernilai 1 (satu) menunjukkan bahwa jumlah staf dan beban kerja di suatu organisasi berada dalam keadaan seimbang. Semakin kecil ratio WISN, semakin besar tekanan beban kerja. Ratio WISN yang kecil menunjukkan bahwa jumlah staf saat ini lebih kecil daripada yang dibutuhkan untuk mengatasi beban kerja yang ada. Sebaliknya, ratio WISN yang besar membuktikan adanya kelebihan staf apabila dibandingkan terhadap beban kerja (WHO, 2010). Berdasarkan teori tersebut dapat dikatakan bahwa unit seksi perencanaan dan pengendalian pada Bidang Bina Marga memiliki beban kerja yang tinggi (rasio WISN $<1$ ).

Mengambil kesimpulan dalam hasil WISN tidak cukup hanya dengan membaca angka-angka namun juga harus diteliti apakah hasil tersebut merupakan akibat tugas-tugas 
profesional tenaga tersebut atau lebih banyak akibat tugas-tugas tambahan diluar tugas profesionalnya. Pada lampiran 6 dan 7 dapat dilihat tugas-tugas pokok dan tambahan pada seksi perencanaan dan pengendalian.

Berdasarkan hasil wawancara dengan kepala bidang, kepala seksi dan bebrapa staff bidang bina marga beban kerja yang tinggi pada seksi perencanaan dan pengendalian terjadi pada awal tahun dimana beberapa kegiatan yang dilakukan seperti survei jalan dan jembatan hampir melibatkan seluruh staff yang berada pada seksi perencanaan dan pengendalian. Kegiatan survei jalan dan jembatan biasanya berlangsung selama 3-4 bulan kemudian pada bulan-bulan setelahnya yaitu sekitar 8 bulan, beban kerja karyawan pada seksi perencanaan tidak akan terlalu tinggi.

2. Unit seksi pembangunan dan peningkatan

Berdasarkan hasil pengolahan data dengan metode WISN ditemukan rasio WISN Bidang Bina Marga 0,8. Rasio WISN tersebut menunjukkan bahwa pada unit seksi pembangunan dan peningkatan terdapat tekanan beban kerja yang tinggi pada beberapa kategori. Kegiatan atau tugas pokok yang memiliki beban kerja tertinggi pada kategori seksi pembangunan dan peningkatan di Bidang Bina Marga adalah kategori kepala seksi, pengawas jalan dan jembatan, dan pengadministrasi umum dan kegiatan (lampiran 6).

3. Unit seksi pemeliharaan

Rasio WISN pada unit seksi pemeliharaan Bidang bina marga menunjukkan angka 0,9. Berdasarkan rasio tersebut tampak bahwa unit pemeliharaan memiliki tekanan beban kerja yang tinggi pada beberapa kategori (rasio WISN $<1$ ). Ketegori yang mengalami tekanan beban kerja adalah kepala seksi dan pengadministrasi umum dan kegiatan. Hal ini dikarenakan seluruh kepala seksi yang ada bina marga merangkap jabatan sebagai PPK dan seluruh pengadministrasi umum di setiap unit juga merangkap sebagai pembantu bendahara seksi.

B. Beban kerja setiap kategori SDM Bidang Bina Marga

Rasio WISN untuk Bidang Bina Marga memperlihatkan beban kerja yang tinggi pada 7 kategori tenaga yaitu: kepala seksi perencanaan, penyusun rencana program, pengadmiistrasi umum dan kegiatan, pembantu umum, kepala seksi pembangunan, pengawas jalan dan jembatan, dan kepala seksi pemeliharaan. Rasio tersebut tidak ada yang menggambarkan beban kerja yang rendah pada setiap kategori, sedangkan kategori tenaga yang memiliki beban kerja seimbang atau sesuai dengan tenaga yang tersedia ada 5 kategori yaitu pengumpul dan pengolah data, juru jalan dan jembatan, pengawas utama, pengawas jalan dan jembatan, dan pelaksana teknis jalan dan jembatan. Komponen yang menentukan tinggi rendahnya beban kerja adalah standar beban kerja yang dibentuk oleh WKT dan standar waktu untuk menyelesaikan satu kegiatan, jumlah kegiatan pokok dan tambahan, frekuensi setiap kegiatan per tahunnya dan jumlah tenaga yang telah tersedia.

Mengetahui beban kerja setiap kategori tenaga yang ada di Bidang Bina Marga dapat dijadikan pedoman untuk mengetahui kebutuhan setiap kategori tenaga yang kemudian dijadikan data dasar dalam membuat perencanaan SDM Bidang Bina Marga. Penyususnan perencanaan SDM merupakan bagian dari rencana strategik Bidang Bina Marga untuk mengantisipasi perkembangan dan tuntutan terhadap organisasi Bidang Bina Marga. Analisis hasil WISN mempertimbangkan kompetensi masing-masing kategori tenaga, komposisi kegiatan-kegiatan pokok dan tambahan, apakah waktu kerja yang dimiliki setiap SDM sebagian besar dihabiskan untuk mengerjakan pekerjaan profesional atau pekerjaan tambahan. Dari hasil analisis terhadap masing-masing unit kerja dan 
kategori SDM pada Bidang Bina Marga Dinas PUPR Kab. Lombok barat didapatkan hasil bahwa beban kerja pada setiap unit kerja masih belum optimal.

4.2.2. Kebutuhan jumlah dan kompetensi SDM masing-masing unit kerja di Bidang Bina Marga Lombok Barat

A. Kebutuhan jumlah dan kompetensi SDM unit kerja

1. Unit seksi perencanaan dan pengendalian

Berdasarkan data primer yang telah diolah, unit perencanaan dan pengendalian Bidang Bina Marga membutuhkan 16 orang tenaga. Saat ini telah tersedia 11 orang tenaga pada unit perencanaan dan pengendalian di Bidang Bina Marga. Berdasarkan data tersebut dapat disimpulkan terdapat kekurangan 5 orang tenaga di Bidang Bina Marga.

Dari hasil wawancara terhadap para karyawan pada unit perencanaan dan pengendalian didapatkan bahwa kompetensi tenaga yang bertugas sebagai staff teknis seharusnya diberikan standar minimal yaitu STM, karena masih ada beberapa staff yang berlatar belakang pendidikan SMA bekerja pada bagian teknis. Kemudian terkait dengan pelatihan, seluruh karyawan pada bidang bina marga belum mendapatkan pelatihan komputer yang diperlukan untuk kegiatanya, dan seluruh kepala seksi juga belum mendapatkan pendidikan dan pelatihan kepemimpinan (DIKLATPIM).

2. Unit seksi pembangunan dan peningkatan

Berdasarkan hasil perhitungan WISN pada seksi pembangunan dan peningkatan membutuhkan 13 orang tenaga sedangkan tenaga yang tersedia 10 orang, sehingga masih terdapat kekurangan 3 orang tenaga. Kategori tenaga yang dibutuhkan adalah 1 orang PPK pembangunan, 1 orang pengawas jalan dan jembatan, dan 1 orang pengadministrasi umum dan kegiatan.

Wawancara terhadap karyawan pada seksi pembangunan dan peningkatan didapatkan data bahwa selain dari pendidikan dan pelatihan yang perlu ditingkatkan, diperlukan juga kesesuaian nama untuk tugas pokok dan fungsi mereka. Karena pada seksi pembangunan dan peningkatan terdapat beberapa karyawan yang mengerjakan pekerjaan yang tidak sesuai dengan TUPOKSI yang ada. Seperti kegiatan yang dilakukan oleh pengawas jalan dan jembatan, jumlah pengawas jalan dan jembatan pada data adalah 5 orang namun pada lapangan yang melakukan kegiatan tersebut hanya 3 orang dan 2 orang lainya di fungsikan sebagai pengawas utama, sehingga jumlah yang tepat adalah 3 orang pengawas utama dan 3 orang pengawas jalan dan jembatan, karena setiap pengawas jalan dan jembatan harus dibawahi oleh pengawas utama untuk setiap paket pekerjaan mereka.

3. Unit seksi pemeliharaan

Berdasarkan data primer yang telah diolah, unit pemeliharaan Bidang Bina Marga membutuhkan 19 orang tenaga. Saat ini telah tersedia 17 orang tenaga pada unit pemeliharaan di Bidang Bina Marga. Berdasarkan data tersebut dapat disimpulkan terdapat kekurangan 2 orang tenaga di Bidang Bina Marga.

Dari hasil wawancara dengan beberapa karyawan pada seksi pemeliharaan terkait dengan kompetensi terdapat ketidaksesuaian penempatan seperti yang berlatar pendidikan SMA ditempatkan pada tipe staf teknis dan yang berpendidikan STM ditempatkan pada tipe staff non teknis.

B. Kebutuhan dan kompetensi setiap kategori SDM Bidang Bina Marga

Berdasarkan kebutuhan setiap kategori tenaga yang ada di setiap unit kerja Bidang Bina Marga, dapat dihitung kebutuhan secara keseluruhan setiap kategori SDM yang ada di Bidang Bina Marga. Bidang Bina Marga Dinas PUPR Kabupaten Lombok Barat secara umum memiliki kebutuhan 49 tenaga dengan tenaga yang tersedia 39 orang sehingga 
masih terdapat kekurangan 10 orang tenaga (tabel 4.10). Jenis kompetensi tenaga yang ada di Bidang Bina Marga meliputi tenaga teknis dan non non teknis. Tenaga yang harus dimiliki Bidang Bina Marga adalah: kepala seksi/PPK perencanaan dan pengendalian, kepala seksi/PPK pembangunan dan peningkatan, kepala seksi/PPK pemeliharaan, penyusun rencana program, pengumpul dan pengolah data, juru jalan dan jembatan, pengadministrasi umum dan kegiatan, pembantu umum, pengawas utama, pengawas jalan dan jembatan, pelaksana teknis jalan dan jembatan. Selain pendidikan formal, kompetensi juga diukur dari pengetahuan, keterampilan yang didapatkan melalui pendidikan dan pelatihan.

Berdasarkan standar kompetensi yang ada sebagian besar SDM Bidang Bina Marga sudah memiliki kompetensi yang sesuai standar baik dari segi pendidikan formal maupun pendidikan dan pelatihan yang pernah diikuti. Beberapa tenaga yang masih berpendidikan SMA atau kategori tenaga lainnya yang belum mengikuti pendidikan dan pelatihan direncanakan secara bertahap untuk meningkatkan kompetensinya. Berdasarkan jenis pelayanan yang diberikan jika dianalisis jumlah kebutuhan tenaga berdasarkan beban kerjanya, maka hasil perhitungan WISN dapat mewakili, karena sudah didasarkan pada kebutuhan riil seluruh kegiatan yang ada di Bidang Bina Marga.

4.2.3. Analisis biaya investasi pengadaan dan kompensasi kebutuhan SDM di Bidang Bina Marga Dinas PUPR Kabupaten Lombok Barat.

Kompetensi adalah salah satu komponen yang perlu dianalisis setelah melakukan perhitungan kebutuhan tenaga dengan metode WISN. Peningkatan kemampuan intelektual dan emosional dilakukan dengan pengembangan SDM berbasis kompetensi. Tingkat kompetensi seseorang dipengaruhi oleh tingkat pendidikan yang dimiliki dan pelatihan yang pernah diikuti. Untuk meningkatkan kompetensi SDM Bidang Bina Marga dapat ditempuh dengan melakukan pendidikan dan pelatihan secara berkelanjutan sesuai dengan kebutuhan Bidang Bina Marga. Melakukan estimasi kebutuhan akan pelatihan dan pengembangan sangat penting dilakukan agar perencanaan pengembangan SDM Bidang Bina Marga tepat sasaran sesuai dengan kebutuhan Bidang Bina Marga.

Tabel 4.13. Jenis pengadaan dan kompensasi kebutuhan

Berdasarkan kategori SDM Bidang Bina Marga

\begin{tabular}{|c|c|c|c|}
\hline No. & Kategori Tenaga & Jenis Pengadaan & $\begin{array}{c}\text { Kompensasi } \\
\text { Kebutuhan }\end{array}$ \\
\hline 1. & $\begin{array}{l}\text { Kepala Bidang } \\
\text { Bina Marga }\end{array}$ & $\begin{array}{ll}\text { - } & \text { Pendidikan lanjutan S2 } \\
\text { - } & \text { DIKLATPIM }\end{array}$ & $\begin{array}{ll}\text { - } & \text { Rp.60.000.000 } \\
\text { - } & \text { Rp.22.125.000 }\end{array}$ \\
\hline 2. & $\begin{array}{l}\text { Kepala seksi } \\
\text { perencanaan dan } \\
\text { pengendalian }\end{array}$ & $\begin{array}{ll}- & \text { DIKLATPIM } \\
- & \text { Pelatihan perhitungan } \\
& \text { biaya pekerjaan jalan dan } \\
& \text { jembatan }\end{array}$ & - $\quad$ Rp.20.230.000 \\
\hline 3. & $\begin{array}{l}\text { Kepala seksi } \\
\text { pembangunan } \\
\text { dan peningkatan }\end{array}$ & $\begin{array}{ll}- & \text { Pendidikan lanjutan S2 } \\
\text { - } & \text { DIKLATPIM } \\
\text { - } & \text { Pelatihan perhitungan } \\
& \text { biaya pekerjaan jalan dan } \\
& \text { jembatan }\end{array}$ & $\begin{array}{ll}\text { - } & \text { Rp. } 60.000 .000 \\
\text { - } & \text { Rp. } 20.230 .000\end{array}$ \\
\hline 4. & $\begin{array}{l}\text { Kepala seksi } \\
\text { pemeliharaan }\end{array}$ & $\begin{array}{ll}\text { - } & \text { Pendidikan lanjutan S2 } \\
\text { - } & \text { DIKLATPIM } \\
\text { - } & \text { Pelatihan perhitungan } \\
& \text { biaya pekerjaan jalan dan } \\
& \text { jembatan }\end{array}$ & $\begin{array}{ll}\text { - } & \text { Rp. } 60.000 .000 \\
\text { - } & \text { Rp. } 20.230 .000\end{array}$ \\
\hline
\end{tabular}




\begin{tabular}{|c|c|c|c|}
\hline 5. & $\begin{array}{l}\text { Penyusun } \\
\text { rencana program }\end{array}$ & - $\quad$ Pendidikan lanjutan S2 & - $\quad$ Rp.60.000.000 \\
\hline 6. & $\begin{array}{l}\text { Pengumpul dan } \\
\text { pengolah data }\end{array}$ & $\begin{array}{ll}\text { - } & \text { Pendidikan lanjutan S1 } \\
\text { Teknik }\end{array}$ & - $\quad$ Rp.37.500.000 \\
\hline 7. & Pengawas utama & $\begin{array}{l}\text { - } \quad \text { Pelatihan computer (Ms. } \\
\text { Office, Auto cad, dll yang } \\
\text { relevan) }\end{array}$ & - $\quad$ Rp.10.000.000 \\
\hline 8. & $\begin{array}{l}\text { Pengawas jalan } \\
\text { dan jembatan }\end{array}$ & $\begin{array}{ll}\text { - } & \text { Pendidikan lanjutan S1 } \\
\text { Teknik } \\
\text { - } \\
\text { Pelatihan computer (Ms. } \\
\text { Office, Auto cad, dll yang } \\
\text { relevan) }\end{array}$ & $\begin{array}{ll}- & R p .37 .500 .000 \\
\text { - } & \\
\text { - } & \text { Rp.10.000.000 }\end{array}$ \\
\hline 9. & $\begin{array}{l}\text { Juru jalan dan } \\
\text { jembatan }\end{array}$ & $\begin{array}{ll}\text { - } & \text { Pendidikan lanjutan S1 } \\
\text { Teknik } \\
\text { - } \quad \text { Pelatihan computer (Ms. } \\
\text { Office, Auto cad, dll yang } \\
\text { relevan) }\end{array}$ & $\begin{array}{ll}\text { - } & \text { Rp.37.500.000 } \\
\text { - } & \text { Rp.10.000.000 }\end{array}$ \\
\hline 10. & $\begin{array}{l}\text { Pelaksana teknis } \\
\text { jalan dan } \\
\text { jembatan }\end{array}$ & $\begin{array}{ll}\text { - } & \text { Pendidikan lanjutan S1 } \\
\text { Teknik } \\
\text { - } \quad \text { Pelatihan computer (Ms. } \\
\text { Office, Auto cad, dll yang } \\
\text { relevan) }\end{array}$ & $\begin{array}{ll}- & \text { Rp.37.500.000 } \\
\text { - } & \text { Rp.10.000.000 }\end{array}$ \\
\hline 11. & $\begin{array}{l}\text { Pengadministrasi } \\
\text { umum dan } \\
\text { kegiatan }\end{array}$ & & \\
\hline 12. & Pembantu umum & & \\
\hline
\end{tabular}

Sumber: BKD, bpsdm.pu.go.id

Berdasarkan tabel 4.13. diatas dapat dilihat kebutuhan pengembangan SDM Bidang Bina Marga terdiri atas peningkatan jenjang pendidikan formal dan pelatihan terkait dengan tugas pokok dan fungsi pada unit kerja dan kategori masing-masing. Untuk kekurangan 10 orang tenaga sesuai dengan hasil analisis WISN Bidang Bina Marga dapat melakukan pemindahan atau mengambil tenaga pada bidang lain yang memiliki kelebihan tenaga atau Bidang Bina marga melakukan reorganisasi kemudian merekrut tenaga kontrak untuk mengisi kategori yang kekurangan. Biaya untuk melakukan pengadaan 10 orang tenaga ini adalah sebesar Rp.90.000.000 dalam satu tahun.

\section{SIMPULAN DAN SARAN}

\subsection{Simpulan}

Terdapat 5 kategori tenaga pada 3 unit kerja di Bidang Bina Marga yang memiliki tekanan beban kerja tinggi (rasio WISN $<1$ ). Beban kerja yang sesuai dengan jumlah ketersediaan tenaga (rasio WISN=1) ditemukan pada 3 unit kerja dan 5 kategori tenaga, sedangkan beban kerja rendah (rasio WISN $>1$ ) tidak ditemukan pada setiap kategori tenaga. Berdasarkan perhitungan beban kerja tersebut terdapat 3 unit kerja dan 5 kategori tenaga yang membutuhkan tambahan tenaga. Kebutuhan SDM Bidang Bina Marga keseluruhan sebanyak 49 orang. 


\subsection{Implikasi}

\subsubsection{Implikasi teoritis}

1. Hasil penelitian ini dapat memperkaya konsep perencanaan SDM melalui estimasi kebutuhan SDM dengan mengukur beban kerja menggunakan metode WISN.

2. Hasil penelitian ini menggambarkan konsep perencanaan SDM melalui analisis biaya investasi untuk pengadaan dan kompensasi SDM.

3. Hasil penelitian ini dapat digunakan sebagai referensi atau acuan bagi penelitianpenelitian selanjutnya yang terkait dengan perencanaan SDM.

\subsubsection{Implikasi praktis}

1. Hasil pengukuran beban kerja, estimasi jumlah kebutuhan dan pengembangan SDM dalam penelitian ini dapat dijadikan masukan bagi Pemimpin Bidang Bina Marga yang ada di Lombok Barat dalam melakukan perencanaan perekrutan, rotasi maupun pengembangan SDM Bidang Bina Marga.

2. Hasil penelitian ini dapat digunakan untuk membantu mengelola SDM Bidang Bina Marga berdasarkan beban kerja, jumlah kebutuhan, distribusi, jenis kompetensi dan pengembangan yang dibutuhkan tiap unit maupun kategori tenaga yang ada di Bidang Bina Marga.

3. Hasil penelitian ini dapat berkontribusi dalam peningkatan kualitas pelayanan Bidang Bina Marga melalui perencanaan SDM Bidang Bina Marga yang baik.

5.3. Saran

1. Setiap organisasi perlu melakukan analisis perencanaan SDM untuk setiap unit dan kategori tenaga yang ada agar jumlah, distribusi, dan kompetensinya sesuai dengan beban kerja yang ada.

2. Organisasi dapat menggunakan metode WISN dalam menghitung beban kerja dan jumlah kebutuhan SDM serta dapat menganalisis biaya investasi pengadaan dan kompensasi SDM.

3. Berdasarkan hasil penelitian, Bidang Bina Marga disarankan melakukan perekrutan kategori SDM yang belum memadai, melakukan rotasi tenaga dari unit yang kelebihan tenaga ke unit yang kekurangan, serta meningkatkan kompetensi SDM Bidang Bina Marga melalui pendidikan dan pelatihan.

4. Metode pengambilan data primer untuk mengukur beban kerja yang digunakan dalam penelitian ini adalah daily log yaitu dengan angket berupa template kegiatan, metode ini sangat bergantung dengan kerjasama dan kejujuran responden dalam mengisi angket. Penelitian selanjutnya disarankan menggunakan metode observasi seperti work sampling atau time motion study agar standar beban kerja yang didapatkan benar-benar sesuai dengan kondisi riil di lapangan.

\section{DAFTAR PUSTAKA}

Abdideh, M. et al, (2014)," Standard Development of Family Physicians to the Population Defined by WISN", Buletin of Environment Pharmachology and Lyfe Science. 3(12): 89-96

Arikunto, S. (2006). Prosedur Penelitian Suatu Pendekatan Praktik, Edisi Revisi VI. Jakarta: Rineka Cipta.Handoko, T. Hani. (1995). Manajemen Personalia dan Sumber Daya Manusia. Yogyakarta: BPFE. 
Awadh, A.P \& Chandel, S. (2015),"Human Resource Assessement of A District Hospital Applying WISN Method: Role of Laboratory Technicians", International Journal of Medicine and Public Health, 3(4): 267-270.

Benhard, R.L. dkk, (2015),"Perencanaan Kebutuhan Sumberdaya Manusiadi Puskesmas Kabupaten Minahasa", JIKMU.5(1):43-53.

Bungin, (2009), Penelitian Kualitatif, Jakarta: Kencana Prenada Media Group.

Dessler, Gary (1984), Manajemen Personalia Teknik dan Konsep Modern, Edisi ke-3, Jakarta: Erlangga.

Dharmayuda, Agung, (2014),"Analisis Beban Kerja Dokter Umum Menggunakan Metode Workload Indicators of Staffing Need (WISN) di Puskesmas Se-kota Denpasar", Pascasarjana Program Megister Kesehatan Masyarakat, Universitas Udayana.Hasibuan, Malayu. (2001). Manajemen Sumber Daya Manusia, Jakarta: Bumi Aksara.

Fitriah, N (2016),"Analisis Kebutuhan Psikiater Berdasarkan Beban Kerja dengan Menggunakan Workload Indicators of Staffing Needs (WISN) di Unit Rawat Jalan Rumah Sakit Jiwa Ernald Bahar Provinsi Sumatera Selatan", Jurnal Kedokterandan Kesehatan, 3(1): 347-353

Govulo, P, et al, (2015),"Application of Workload Indicators of Staffing Needs (WISN) in Determining Health Workers Requirements for Mityana General Hospital, Uganda", International Journal of Public Health Research, 3(5): 254-263

Herdiansyah, haris. (2010). Metodologi Penelitian Kuantitatif. Jakarta: Salemba Humanika. Ilyas, Yaslis. 2011, Perencanaan SDM Rumah Sakit: Teori, Metode dan Formulasi, Cetakan Ketiga, Depok: Fakultas Kesehatan Masyarakat, Universitas Indonesia,

Lolowang, Adolfina, Lumintang. 2016, Pengaruh pelatihan dan pengembangan sumber daya manusia terhadap kinerja karyawan pada PT. Berlian Kharisma Pasifik Manado

Mangkunegara, Anwar Prabu, (2003), Perencanaan dan Pengembangan Sumberdaya Manusia, Bandung: Refika Aditama.

Manullang, Marihot. (2011). Manajemen Personalia. Yogyakarta: Gadjah Mada University Press.

Moekijat. (1995). Manajemen Personalia dan Sumber Daya Manusia. CV. Mandar Maju. Bandung

Nazir, Muhammad, (2003), Metode Penelitian, Jakarta: Ghalia Indonesia.

Notoatmodjo, Soekodjo, (2003), Pengembangan Sumber Daya Manusia. Jakarta: Rineka Cipta

Rivai, Veithzal, (2004), Manajemen Sumberdaya Manusia untuk Perusahaan dari Teori ke Praktik, Cetakan Pertama, Jakarta, Prajagrafindo Persada.

Robbins, Stephen.P, (1999), Perilaku Organisasi, Jilid I. Jakart : Erlangga.

Saikat, D. et al,(2013)," A study to Calculate the Nursing Staff Requirements for the Maternity Ward of Medical Collage Hospital, Kolkata Applying WISN Method", IOSR Journal of Dental and Medical Sciences. 8(3): 01-07.

Sangaji, Etta Mamang dan Sopiah. (2010). “Metodologi Penelitian”. ANDI: Yogyakarta

Satish, N. et al, (2015)," Gap analysis in Staffing Using Workload Indicators of Staffing Need Method in A Tertiary Care Teaching Hospital", International Journal of Scientific Research, 4(7): 376-377.

Setyawan, T. (2008)," Analisis Beban Kerja Dan Kebutuhan Sumber Daya Manusia", Jurnal Manajemen Vol 1, No. 1.

Shipp, P.J., (1998), Workload Indicators of Staffing Needs (WISN): Manual for Implementation, Boston, USA: Initiatives Inc. 
Simamora, Henry, (2006), Manajemen Sumberdaya Manusia, Edisi ke-3, Cetakan ke-2, Yogyakarta: STIE YKPN

Sukmawati, A. (2013),"Analisis Beban Kerja Sumber Daya Manusia dalam Aktivitas Produksi Komoditi Sayuran Selada (Studi Kasus: CV Spirit Wira Utama)”, Jurnal Manajemen dan Organisasi Vol IV, No. 2

Wicaksono. 2016, Pengaruh pelatihan dan pengembangan sumber daya manusia dalam rangka meningkatkan semangat kerja dan kinerja karyawan (Studi di SKM Unit V PT. Gudang Garam, Tbk Kediri).

Wangi, W.S. (2017), “Analisis Perencanaan Sumberdaya Manusia (SDM) Kesehatan Puskesmas dengan Metode Workload Indicators of Staffing Needs (WISN) di Kabupaten Lombok Barat", Tesis Program Pascasarjana Magister Manajemen, Universitas Mataram.

WHO, (2010), Workload Indicators of Staffing Needs (WISN), Janeva: WHO Press. (2004), Dinas Pekerjaan Umum, 2004. "Undang-Undang Republik Indonesia Nomor 38 Tahun 2004 tentang Jalan". Badan Penerbit Pekerjaan Umum. , (2007), Peraturan Pemerintah Republik Indonesia Nomor 15 Tahun 2007 Tata Cara Memperoleh Informasi Ketenagakerjaan dan Penyusunan Serta Pelaksanaan Perencanaan Tenaga Kerja, Jakarta: Lembaran Negara Republik Indonesia Tahun 2007 Nomor 34. (2012), Peraturan Pemerintah Republik Indonesia Nomor 64 Tahun 2012 Tentang

Sistem Manajemen Sumberdaya Manusia Pada Ombudsman Republik Indonesia, Jakarta: Pemerintah Republik Indonesia.

(2016), Peraturan Bupati Lombok Barat Nomor 60 Tahun 2016, Tentang Tugas dan Tanggung Jawab Bidang Bina Marga Dinas Pekerjaan Umum dan Penataan Ruang Kabupaten Lombok Barat. 